\title{
Prevalence of subclinical hypothyroidism in North-Indian pregnant women
}

\author{
Manisha Goel*, Amita Sharma, Alpana Agrawal, Manisha Gupta
}

Department of Obstetrics \& Gynaecology, Santosh Medical College and Hospital, Ghaziabad, UP, India

Received: 15 May 2015

Accepted: 06 June 2015

\author{
*Correspondence: \\ Dr. Manisha Goel, \\ E-mail: manisha_07mittal@yahoo.co.in
}

Copyright: (c) the author(s), publisher and licensee Medip Academy. This is an open-access article distributed under the terms of the Creative Commons Attribution Non-Commercial License, which permits unrestricted non-commercial use, distribution, and reproduction in any medium, provided the original work is properly cited.

\begin{abstract}
Background: It is now well established that not only overt but subclinical thyroid dysfunction can also have adverse effects on fetal and maternal outcomes. In recent years several studies show a much larger prevalence of SCH and marked variation between different ethnic groups. The aim of this study was to find out the prevalence of subclinical hypothyroidism during first trimester in a teaching hospital in North India.

Methods: A prospective observational study was conducted in all the consecutive first trimester pregnant women attending Santosh Medical College, Hospital, Ghaziabad from June 2014 to April 2015 after institutional ethics approval and consent from the study subjects. Morning samples of serum were tested for TSH. If serum TSH value was more than $2.5 \mathrm{mIU} / \mathrm{L}$ then Free T4 and TPO Antibody level were estimated.

Results: Serum TSH level was normal in $66.2 \%$ women, $32.5 \%$ women had subclinical hypothyroidism and $1.3 \%$ women had overt hypothyroidism using a first trimester normal reference range of 0.1 to $2.5 \mathrm{mU} / 1$ suggested by American Thyroid Association or by the American Endocrine Society.

Using $5 \mathrm{mIU} / \mathrm{L}$ as upper limit of TSH suggested by some Indian studies serum TSH level was normal in $90.6 \%$ women, $8.1 \%$ women had subclinical hypothyroidism and $1.3 \%$ women had overt hypothyroidism.

Conclusion: The prevalence of SCH is very high in our study population. We feel that the use of thyroid function reference values based on studies using different populations and different backgrounds can introduce bias in the evaluation of a local population.
\end{abstract}

Keywords: Pregnancy, Overt hypothyroidism $(\mathrm{OH})$, Sub clinical hypothyroidism (SCH), Prevalence

\section{INTRODUCTION}

Subclinical hypothyroidism $(\mathrm{SCH})$ in pregnancy is defined by a serum thyroid-stimulating hormone (TSH) concentration higher than the upper limit of the pregnancy related reference range associated with a normal serum thyroxine [T 4; either total (TT 4) or free (FT 4 )] concentration.

The prevalence of hypothyroidism during pregnancy is estimated to be $0.3-0.5 \%$ for overt hypothyroidism $(\mathrm{OH})$ and $2-3 \%$ for subclinical hypothyroidism $(\mathrm{SCH}) .{ }^{1}$ There are few reports of prevalence of hypothyroidism during pregnancy from India with prevalence rates ranging from $4.8 \%$ to $14.3 \% .^{2-4}$ It is now well established that not only overt but subclinical thyroid dysfunction can also have adverse effects on fetal and maternal outcome. Current data indicate an increase in pregnancy loss, gestational diabetes, gestational hypertension, pre-eclampsia and preterm delivery in women with $\mathrm{SCH}$ in pregnancy. The association between $\mathrm{SCH}$ in pregnancy and impaired neuropsychological development of the offspring is inconsistent.

Many of these adverse effects could be prevented or ameliorated by early detection and appropriate treatment. Using the recent Endocrine Society clinical practice guidelines, $2.5 \mathrm{mIU} / \mathrm{L}$ of Thyroid Stimulating Hormone as the upper level of normal in the first trimester and 3.0 $\mathrm{mIU} / \mathrm{L}$ in the second and third trimester, ${ }^{5}$ there have been 
several studies showing a much larger prevalence of SCH and marked variation between different ethnic groups.

It is a matter of discussion whether these reference ranges should be used worldwide. Two studies from China and one study from India, ${ }^{6}$ for example, demonstrated a significantly higher TSH reference range for each trimester. The Indian study by Marwah et al. ${ }^{6}$ showed that the Indian population displays $0.6-5.0 \mathrm{mU} / \mathrm{l}$ as first trimester reference range and they recommended it for evaluation of pregnant Indian women.

The aim of this study was designed to evaluate the prevalence of sub clinical hypothyroidism during pregnancy in women attending a teaching hospital in North India.

\section{METHODS}

This was a prospective observational study involving 615 pregnant women attending antenatal clinics of the Department of Obstetrics and Gynaecology of Santosh Medical College Ghaziabad in their first trimester.

They were subjected to clinical evaluation with emphasis on the family history of thyroid disorder and the obstetric history.

Serum TSH estimations were done as initial hormonal investigations after informed consent. Free T4 (FT4) and thyro-peroxidase antibody (TPO Antibody) level estimation were determined if TSH levels were deranged. The reference range used for thyroid dysfunction was: first trimester, 0.1-2.5 mIU/L; second trimester, 0.2-3.0 $\mathrm{mIU} / \mathrm{L}$; third trimester, 0.3-3.0 mIU/L, as per American Thyroid Association (ATA) and Endocrine Society Clinical Practice Guidelines (2012) recommendations We also analyzed the results using $0.6-5.0 \mathrm{mU} / 1$ as first trimester reference $0.6-5.0 \mathrm{mU} / 1$ recommended by Marwah et al. ${ }^{6}$
Estimation of free T4, and TSH was carried out using using chemiluminescence Immunoassay (CLIA) technique, and anti-TPO was carried out by using Hycor kits by ELISA method in a National Accreditation Board for Testing and Calibration Laboratories (NABL) accredited lab.

The study period was from June 2014 to April 2015. Pregnant women with known current or past thyroid disorders were excluded from the study.

Data were analyzed using Medcalc (Version 12.6.0). Continuous variables were expressed as mean \pm standard deviation (SD).

\section{RESULTS}

The baseline characteristics of study population are given in Table $1 \& 2$. The mean (SD) age of study subjects was $25.4( \pm 3.61)$ years .In the study group $48.6 \%$ of women belonged to age group 21-25 years and $37.5 \%$ of women belonged to age group 26-30 years .(Table 1, Fig. 1)

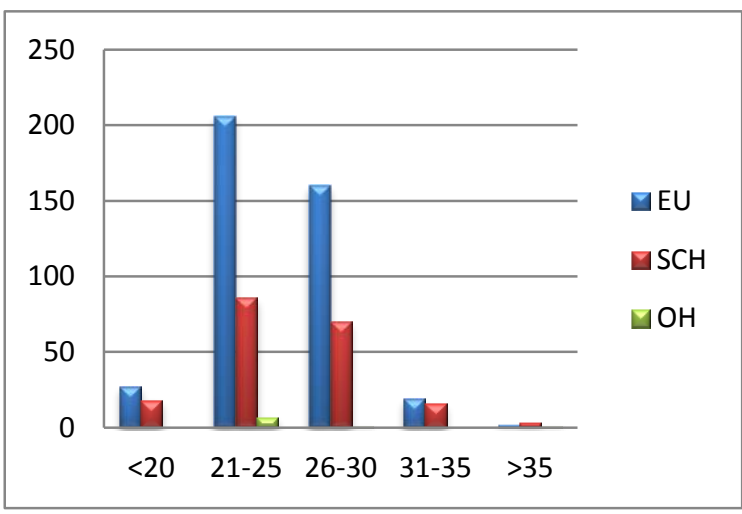

Figure 1: Age distribution of study population.

Among all women, $38.5 \%$ were primigravida and $61.5 \%$ were multigravida.

Table 1: Demographic profile.

\begin{tabular}{|lllll|} 
& $\begin{array}{l}\text { Euthyroid } \\
\mathrm{n}(\%)\end{array}$ & $\begin{array}{l}\text { Subclinical } \\
\text { Hypothyroidism } \\
\mathrm{n}(\%)\end{array}$ & $\begin{array}{l}\text { Overt } \\
\text { Hypothyroidism } \\
\mathrm{n}(\%)\end{array}$ & Total \\
\hline $\mathrm{n}$ (Number of cases) & $407(66.2)$ & $200(32.5)$ & $8(1.3)$ & 615 \\
\hline $\begin{array}{l}\text { Age in years } \\
(\text { mean } \pm \mathrm{SD})\end{array}$ & $25.3( \pm 3.45)$ & $25.95( \pm 3.93)$ & $22.8( \pm 1.83)$ & $25.4( \pm 3.61)$ \\
\hline$\leq 20 \mathrm{n}(\%)$ & $27(60)$ & $18(40)$ & 0 & $45(7.3)$ \\
\hline $21-25 \mathrm{n}(\%)$ & $206(68.9)$ & $86(28.8)$ & $7(2.3)$ & $299(48.6)$ \\
\hline $26-30 \mathrm{n}(\%)$ & $160(69.2)$ & $70(30.3)$ & $1(.4)$ & $231(37.5)$ \\
\hline $31-35 \mathrm{n}(\%)$ & $19(54.3)$ & $16(45.7)$ & 0 & $35(5.7)$ \\
\hline$>35 \mathrm{n}(\%)$ & $2(40)$ & $3(60)$ & 0 & $5(.8)$ \\
\hline Primigravida & $162(68.4)$ & $68(28.7)$ & $7(2.9)$ & $237(38.5)$ \\
\hline Multigravida & $246(65)$ & $131(34.7)$ & $1(.3)$ & $378(61.5)$ \\
\hline
\end{tabular}


The mean (SD) gestational age was $9.8( \pm 1.66)$ weeks. All the study subjects belonged to either poor or lower middle socioeconomic status. Blood pressure was normal in all the study subjects. The mean (SD) hemoglobin was $10.7( \pm 1.31) \mathrm{g} / \mathrm{dl}$. The mean $(\mathrm{SD}) \mathrm{TSH}$ was $2.71( \pm 1.92)$ $\mu \mathrm{IU} / \mathrm{L}$. (Table 2)

Table 2: Demographic profile.

\begin{tabular}{|lll|}
\hline Parameters & Mean & SD \\
\hline Age (years) & 25.4 & 3.61 \\
\hline Gestational age (weeks) & 9.8 & 1.66 \\
\hline $\mathrm{Hb}(\mathrm{g} / \mathrm{dL})$ & 10.7 & 1.31 \\
\hline $\mathrm{TSH}(\mu \mathrm{IU} / \mathrm{L})$ & 2.71 & 1.92 \\
\hline
\end{tabular}

Serum TSH level was normal in $66.2 \%$ women, $32.5 \%$ women had sub clinical hypothyroidism and $1.3 \%$ women had overt hypothyroidism using a first trimester normal reference range of 0.1 to $2.5 \mathrm{mU} / \mathrm{l}$ suggested by American Thyroid Association or by the American Endocrine Society. Anti-TPO Antibody was present in $15 \%$ of women having overt hypothyroidism and in $12.5 \%$ of women having subclinical hypothyroidism. (Table 3)

Table 3: Thyroid status (using trimester specific normal range $\geq 2.5 \mathrm{mIU} / \mathrm{I}$ as upper limit of TSH in $1^{\text {st }}$ trimester).

\begin{tabular}{|lll|}
\multicolumn{1}{l|}{} & $\mathrm{n}(\%)$ & $\begin{array}{l}\text { Anti-TPO } \\
\text { Ab (\%) }\end{array}$ \\
\hline Overt Hypothyroidism & $8(1.3 \%)$ & $1(12.5 \%)$ \\
\hline Subclinical Hypothyroidism & $200(32.5 \%)$ & $30(15 \%)$ \\
\hline Euthyroid & $407(66.2 \%)$ & \\
\hline Total & 615 & \\
\hline
\end{tabular}

Using $5 \mathrm{mIU} / \mathrm{L}$ as upper limit of $\mathrm{TSH}$ suggested by Indian studies ,serum TSH level was normal in $90.6 \%$ women, $8.1 \%$ women had sub clinical hypothyroidism and $1.3 \%$ women had overt hypothyroidism. (Table 4)

Table 4: Thyroid status (Using 5 mIU/I as upper limit of TSH).

\begin{tabular}{|ll|}
\hline Overt Hypothyroidism & n ( \%) \\
\hline Subclinical Hypothyroidism & $8(1.3 \%)$ \\
\hline Euthyroid & $50(8.1 \%)$ \\
\hline Total & $557(90.6 \%)$ \\
\hline
\end{tabular}

\section{DISCUSSION}

Hypothyroidism, especially subclinical, is common in North Indian women. In our study, Serum TSH level was normal in $66.2 \%$ women, $32.5 \%$ women had sub clinical hypothyroidism and $1.3 \%$ women had overt hypothyroidism using a first trimester normal reference range of 0.1 to $2.5 \mathrm{mU} / 1$ which is very high.

Using $5 \mathrm{mIU} / \mathrm{L}$ as upper limit of TSH suggested by an Indian study, ${ }^{6}$ serum TSH level was normal in $90.6 \%$ women, $8.1 \%$ women had sub clinical hypothyroidism and $1.3 \%$ women had overt hypothyroidism.

Using trimester specific ranges proposed by recent guidelines there have been several studies showing a much larger prevalence of $\mathrm{SCH}$ and marked variation between different ethnic groups. The prevalence of any degree of hypothyroidism in pregnancy has varied from $12.3 \%$ (Finnish), 15.5\% (American), 35.3\% (South American) to $17 \%$ (Danish) in these recent studies. ${ }^{7-10}$.In the American study with samples from over half a million pregnant women, there were significant differences in the prevalence of hypothyroid disorders among Asian American women (19.3\%) compared to African Americans (6.7\%) and Caucasians (16.4\%). ${ }^{8}$

Dhanwal et al. ${ }^{4}$ from Delhi in 2013 reported a hypothyroidism prevalence of $14.3 \%$, with a cut- off of $4.5 \mathrm{mIU} / \mathrm{L}$ as upper limit of normal in a cohort of 1000 pregnant women. In our study with a cut-off of $5 \mathrm{~m} \mathrm{IU/L}$ as upper limit of TSH in first trimester suggested by an Indian study, ${ }^{6}$ the prevalence rate came down from $32.5 \%$ to $8.1 \%$.

A Chinese study by Li et al. ${ }^{11}$ showed that the Chinese population displays $0.12-5.08 \mathrm{mU} / \mathrm{l}$ as first trimester reference range; as a consequence, using the suggested $0.1-2.5 \mathrm{mU} / \mathrm{l}$ as reference range, about $28 \%$ of the pregnant patients in China would suffer from hypothyroidism, versus $4 \%$ when using an ethnically specific reference range. Not all of them will have thyroid disease.

Although there are still no well-controlled studies to justify universal screening, but it may detect unknown overt hypothyroidism with the beneficial effects of levothyroxine treatment, on obstetric outcome. The targeted approach will miss a large percentage of women with $\mathrm{SCH}$, especially in mildly iodine-deficient women in country like India.

ATA/AACE guidelines suggests treatment of all $\mathrm{SCH}$ pregnant women regardless of the antibody status when TSH serum concentrations exceed the pregnancy specific upper limits of $2.5 \mathrm{mU} / \mathrm{l}$ in the first trimester and 3.0 or $3.5 \mathrm{mU} / 1$ in the following trimesters respectively. ${ }^{5}$ All guidelines agree that "it is reasonable practice to maintain TSH values in women planning pregnancy below $2.5 \mathrm{mU} / \mathrm{L}$, especially in those with positive TPOAb; newly diagnosed patients should be treated in order to normalize maternal serum TSH values within the trimester-specific pregnancy reference range."

The recent ETA guidelines, which generally agreed on a TSH threshold of $>2.5 \mathrm{mU} / \mathrm{l}$ for starting T4 substitution, discussed this question even more controversially by stating that "the debate about substitution therapy in subclinical hypothyroidism is still open both for nonpregnant and pregnant patients" but remained in favour of treatment because the panel believed that "thyroxine 
treatment of SCH would appear to have the potential benefits which outweigh the potential risks". ${ }^{12}$ It is too simplistic to expect a general improvement in pregnancy outcomes and neurodevelopment of the offspring based on this criterion. Several large prospective trials in different countries will hopefully help to clarify these questions in the future. As there is absence of fetal markers to monitor the adequacy of thyroxine treatment currently, a more cautious approach should be adopted towards treating $\mathrm{SCH}$ in pregnancy.

The negative impact of relying on "recommendations" for the interpretation of thyroid laboratory results has been recently commented by Moncayo et al. as: "lack of clinical congruence". ${ }^{13}$ By this they meant a misclassification of subjects by using an arbitrary cut-off value. This concern appears to be shared by other authors also.

\section{CONCLUSION}

The prevalence of $\mathrm{SCH}$ is very high in our study population. We feel that the use of thyroid function reference values based on studies using different populations and different backgrounds can introduce bias in the evaluation of a local population. Studies are needed to establish reference range of TSH in Indian pregnant women for diagnosis of SCH and subsequent treatment.

\section{ACKNOWLEDGEMENTS}

We are grateful to all the women who have taken part in the study.

\section{Funding: No funding sources}

Conflict of interest: None declared

Ethical approval: The study was approved by the Institutional Ethics Committee

\section{REFERENCES}

1. Reid Sm, Middleton P, Cossich MC, Crowther CA. Interventions for clinical and subclinical hypothyroidism in pregnancy. Cochrane Database of Systematic Reviews. 2010;7:1-34.

2. Sahu MT, Das V, Mittal S, Agarwal A, Sahu M. Overt and subclinical thyroid dysfunction among Indian pregnant women and its effect on maternal and fetal outcome. Arch Gynecol Obstet. 2010;281:215-20.

3. Nambiar V, Jagtap VS, Sarathi V, Lila AR, Kamalanathan S, Bandgar TR, et al. Prevalence and impact of thyroid disorders on maternal outcome in Asian-Indian pregnant women. J Thyroid Res. 2011;2011:4290-97.
4. Dhanwal DK, Prasad S, Agarwal AK, Dixit V, Banerjee AK. High prevalence of subclinical hypothyroidism during first trimester of pregnancy in North India. Indian J Endocrinol Metab. 2013;17: 281-4.

5. De Groot L, Abalovich M, Alexander EK, Amino N, Barbour L, Cobin RH, et al. Management of thyroid dysfunction during pregnancy and postpartum: An endocrine society clinical practice Guideline. J Clin Endocrinol Metab. 2012;97:2543-65.

6. Marwaha RK, Chopra S, Gopalakrishnan S, Sharma B, Kanwar RS, Sastry A, et al. Establishment of reference range for thyroid hormones in normal pregnant Indian women. $\mathrm{Br} \mathrm{J}$ Obstet Gynaecol. 2008;115:602-6.

7. Altomare M, LA Vignera S, Asero P, Recupero D, Condorelli RA, Scollo P, et al. High prevalence of thyroid dysfunction in pregnant women. J Endocrinol Invest. 2013;36:407-11.

8. Blatt AJ, Nakamoto JM, Kaufman HW. National status of testing for hypothyroidism during pregnancy and postpartum. J Clin Endocrinol Metab. 2012;97:777-84.

9. Mosso ML, Martínez GA, Rojas MP, Margozzini P, Solari S, Lyng T, et al. Frequency of subclinical thyroid problems among women during the first trimester of pregnancy. Rev Med Chil. 2012;140:1401-8.

10. Feldthusen A, Larsen J, Pedersen P, et al. Pregnancyinduced alterations in mitochondrial function in euthyroid pregnant women and pregnant women with subclinical hypothyroidism; relation to adverse outcome. Journal of Clinical \& Translational Endocrinology. 2014;1(1):e13-7.

11. Li C, Shan Z, Mao J, Wang W, Xie X, Zhou W, et al. Assessment of thyroid function during first-trimester pregnancy: what is the rational upper limit of serum TSH during the first trimester in Chinese pregnant women? J Clin Endocrinol Metab. 2014;99:73-9.

12. Lazarus J, Brown RS, Daumerie C, HubalewskaDydejczyk A, Negro R, Vaidya B. 2014 European Thyroid Association Guidelines for the Management of Subclinical Hypothyroidism in Pregnancy and in Children. European Thyroid Journal. 2014;3:76-94.

13. Moncayo H, Moncayo R. The lack of clinical congruence in diagnosis and research in relation to subclinical hypothyroidism. Fertil Steril. 2014;101:e30

Cite this article as: Goel M, Sharma A, Agrawal A, Gupta M. Prevalence of subclinical hypothyroidism in North-Indian pregnant women. Int J Reprod Contracept Obstet Gynecol 2015;4:1034-7. 